\title{
TERORISME DAN JIHAD DALAM PERSPEKTIF ALQURAN
}

\author{
Gonsales
}

UIN Imam Bonjol Padang, salesgon64@gmail.com

\author{
Diterima: 12 Januari 2018 \\ Direvisi : 23 April 2018 \\ Diterbitkan: 30 Juni 2018
}

\begin{abstract}
Islam constantly calls for peace and togetherness, even condemning violence and terror. However, the charge against Islam as a terrorism ideology is a very heartbreaking thing for the (Muslim) community. However, it can not be denied that there is a tendency in understanding the Qur'an and hadith textually and literally an sich that can lead to behavior that seems anarchist, intolerant, and tend to destructive. Jihad teachings, for example, are often misunderstood as justification for actions and propaganda, radical acts, bombings and terrorism. Seeing the reality that happens, is a necessity to provide a correct understanding of Islam. As a first step, it is necessary to comprehend a comprehensive methodology in understanding nash. There is many discussions in the matter of terrorists and jibad, therefore it must be distinguished between the two with the real meaning in the perspective of the Quran. In this discussion, there will be limited issues to be discussed include the definition of terrorists and jihad, verses that are often misunderstood as justification of terrorism, and how the full point of view of the Quran related to terrorism.
\end{abstract}

Keywords: Terorism, Jibad, Alquran

\begin{abstract}
Abstrak
Islam senantiasa menyerukan aksi perdamaian dan kebersamaan, babkan mengecam kekerasan dan terror. Akan tetapi, tuduban terhadap Islam sebagai ideology terorisme merupakan hal yang sangat memilukan bagi komunitas (muslim). Namun, tidak dipungkiri terdapat kecenderungan dalam memahami Alquran dan Hadis secara tekstual dan literal an sich yang dapat melabirkan perilaku yang terkesan anarkis, tidak. toleran, dan cenderung destruktif. Ajaran jihad misalnya, sering disalahpahami sebagai pembenaran terbadap berbagai aksi dan propaganda, aksi-aksi radikal, aksi-aksi pemboman dan terorisme. Melihat realitas yang terjadi, adalah sebuah keniscayaan untuk memberikan pemahaman yang benar tentang Islam. Sebagai langkah awal, perlu diupayakan pemahaman metodologi komprehensif dalam memahami nash. Ada banyak pembahasan dalam masalah teroris dan jihad, Oleh karena itu harus dibedakan antara keduanya dengan makna yang sesunggubnya dalam perspektif Alquran. Dalam pembabasan ini akan dibatasi permasalahan yang akan dibahas mencakup pengertian teroris dan jibad, ayat-ayat yang kerap disalahpahami sebagai pembenaran terhadap terorisme, dan bagaimana pandangan Alquran seutubnya terkait terorisme.
\end{abstract}

Kata Kunci: Terorisme, Jihad, Alquran

\section{PENDAHULUAN}

Terorisme pada dasarnya merupakan suatu gejala kekerasan yang berkembang sejalan dengan peradaban manusia itu sendiri. Terorisme sebagai kejahatan terhadap kemanusiaan, ditengarai telah ada sejak zaman Yunani Kuno, Romawi Kuno, dan pada abad pertengahan. Dalam konteks ini, terorisme secara klasik diartikan sebagai kekerasan atau ancaman kekerasan yang dilakukan untuk menciptakan rasa takut dalam masyarakat. ${ }^{1}$

Banyak faktor yang men-setting tindakan terorisme dewasa ini. Akan tetapi, tuduhan terhadap Islam sebagai ideology terorisme merupakan hal yang sangat memilukan bagi komunitas kita (muslim). Padahal Islam senantiasa menyerukan aksi perdamaian dan kebersamaan, bahkan
1 Lukmanul Hakim, Terorisme di Indonesia, (Surakarta: FSIS, 2004), h.3 
mengecam kekerasan dan terror. ${ }^{2}$ Sebagaimana dalam ayat, QS. An-Nahl:125.

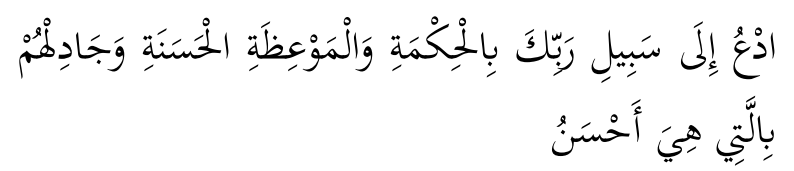

Serulah (manusia) kepada jalan Tuhan-mu dengan bikmah dan pelajaran yang baik dan bantablah mereka dengan cara yang baik.

Mengamati aktivitas keagamaan umat muslim kontemporer, terdapat kecenderungan dalam memahami Alquran dan Hadis secara tekstual dan literal an sich yang dapat melahirkan perilaku yang terkesan anarkis, tidak toleran, dan cenderung destruktif. ${ }^{3}$ Ajaran jihad misalnya, sering disalahpahami sebagai pembenaran terhadap berbagai aksi dan propaganda, aksi-aksi radikal, aksi-aksi pemboman dan terorisme. Melihat realitas yang terjadi, adalah sebuah keniscayaan untuk memberikan pemahaman yang benar tentang Islam. Sebagai langkah awal, perlu diupayakan pemahaman metodologi komprehensif dalam memahami teks Alquran, maupun Hadis.

Ada banyak pembahasan dalam masalah teroris dan jihad, Oleh karena itu harus dibedakan antara keduanya dengan makna yang sesungguhnya dalam perspektif Alquran. Dalam pembahasan ini akan dibatasi permasalahan yang akan dibahas mencakup pengertian teroris dan jihad, ayat-ayat yang kerap disalahpahami sebagai pembenaran terhadap terorisme, dan bagaimana pandangan Alquran seutuhnya terkait terorisme.

\section{TERORISME}

Kata terror berasal dari bahasa latin terrere yang kurang lebih diartikan sebagai kegiatan atau tindakan yang dapat membuat

2 Suhailah Zain al-Abiddin Hammad, Bagaimana Mengatasi Terorisme, ( Jakarta: Zikrul Hakim, 2005), h. v

3 Nasaruddin Umar, Deradikalisasi Pemahaman Al-Qur'an dan Hadis, (Jakarta: Rahmat Semesta Center, 2008), h. 1 pihak lain ketakutan. ${ }^{4}$ Dalam bahasa Indonesia, kata teror dapat berarti usaha menciptakan ketakutan, kengerian, dan kekejaman oleh seseorang atau golongan. ${ }^{5}$ Teroris adalah orang yang menggunakan kekerasan untuk menimbulkan rasa takut, biasanya untuk tujuan politik. Sedangkan terorisme adalah penggunaan kekerasan untuk menimbulkan ketakutan dalam usaha mencapai suatu tujuan. ${ }^{6}$

Dalam bahasa Arab istilah terorisme biasa disamakan dengan kata al-irhab (الارهاب) yang berasal dari pecahan huruf ra-ba dan $b a$ yang mengandung dua arti dasar; pertama menunjuk pada ketakutan, kengerian (yadullu alã khiffatin yang kedua mengandung arti tipis dan ringan (yadullu alã diqqatin wa khiffatin). Terkait dengan judul ini tampaknya arti pertama yang relevan dengan pembahasan. Makanya dalam bahasa Arab dikatakan (هبت saya menakut-nakuti dengan suatu ketakutan. Dari pengertian dasar inilah selanjutnya dipakai untuk menunjuk kata alirbabiyyun (الارهابيون), teroris yang dinisbatkan kepada orang-orang/kelompok yang menempuh jalan kebengisan, kekejaman dan menimbulkan ketakutan kepada lawanlawannya untuk mencapai target-target yang diinginkan (biasanya target politik).

Jadi, secara singkat bisa dikatakan bahwa terorisme merupakan sebuah bentuk kekerasan langsung atau tidak langsung, yang dikenakan pada sasaran yang tidak sewajarnya mendapat perlakuan kekerasan itu, dan dengan aksi tersebut dimaksudkan agar terjadi rasa takut yang luas di tengah-tengah masyarakat. Bila seseorang meledakkan sebuah bom di masjid, gereja, pasar, hotel, pertokoan atau dikerumunan orang maka teroris yang

${ }^{4}$ Lukmanul Hakim, Terorisme di Indonesia., h.2

5 Departemen Pendidikan dan Kebudayaan, Kamus Besar Bahasa Indonesia, (Jakarta: Balai Pustaka, 1990), h. 939

${ }^{6}$ Ibid.

${ }^{7}$ Ibrahim Anis, al-Mu'jam al-Wasith, juz I (Dar al-Fikr: Beirut, t. th.), h. 376. 
meledakkan bom itu mengharapkan segera terjadi suasana ketakutan di tengah-tengah masyarakat. Semakin takut perasaan masyarakat maka semakin berhasil gerakan terorisme.

Menurut Konvensi PBB tahun 1937, terorisme adalah segala bentuk tindak kejahatan yang ditujukan langsung kepada negara dengan maksud menciptakan bentuk teror terhadap orang-orang tertentu atau kelompok orang atau masyarakat luas. ${ }^{8}$

Menurut Muhammad Mustofa, terorisme adalah tindakan kekerasan atau ancaman kekerasan yang ditujukan kepada sasaran secara acak (tidak ada hubungan langsung dengan pelaku) yang berakibat pada kerusakan, kematian, ketakutan, ketidakpastian dan keputusasaan massal. ${ }^{9}$

Undang-undang anti terorisme pasal 6 dan 7 menjelaskan bahwa esensi terorisme adalah setiap orang yang dengan sengaja menggunakan kekerasan atau ancaman kekerasan bermaksud menimbulkan suasana teror atau rasa takut terhadap orang secara meluas atau menimbulkan korban yang bersifat massal, dengan cara merampas kemerdekaan atau hilangnya nyawa dan harta benda orang lain, atau mengakibatkan kerusakan atau kehancuran terhadap obyekobyek vital yang strategis atau lingkungan hidup atau fasilitas publik atau fasilitas internasional. ${ }^{10}$

Berdasarkan beberapa defenisi di atas, dapat diketahui bahwa ciri utama terorisme adalah pertama, penggunaan kekerasan atau ancaman kekerasan dengan tujuan tertentu secara sistematis. Kedua, korban yang ditimbulkan tidak pandang bulu, baik itu musuh atau sekutu, untuk mencapai tujuan tertentu. Ketiga, pelakunya dapat beroperasi

\footnotetext{
8 Loudewijk. F. Paulus, Terorisme”, http://buletinlitbang.dephan.go.id

9 Muhammad Mustofa, "Memahami Terorisme: SuatuPerspektif Kriminolog, Jurnal KriminologiIndonesia FISIP UI, (Jakarta: 2002).

${ }^{10}$ Lukmanul Hakim, Terorisme di Indonesia, h. 17
}

sendiri ataupun anggota kelompok yang telah terorganisasi. Keempat, aksi-aksinya dirancang untuk menarik perhatian dan termotivasi karena tujuan politik atau keyakinan kebenaran yang melatarbelakanginya. Kelima, kegiatan terorisme ditujukan pada suatu pemerintahan, kelompok tertentu, atau partai politik tertentu, dengan tujuan untuk membuat kerusakan di bidang politik, ekonomi, atau social.

Mencermati defenisi terorisme di atas, maka terdapat beberapa term/istilah yang terkait dengan terorisme dalam hukum Islam antara lain al-Irbab (teror), al-Hirabah (perampokan), al-Baghy (pemberontakan),qath'I al-thariq (pembegal), al-unf (lawan dari kelemahlembutan). ${ }^{11}$

\section{PANDANGAN ALQURAN TENTANG TERORISME}

Islam sebagai agama rahmat bagi seluruh alam tidak mendasarkan diri kepada pemaksaan apalagi kekerasan. Sebagaimana diterangkan dalam firman-Nya dalam Surat AlBaqarah ayat 256.

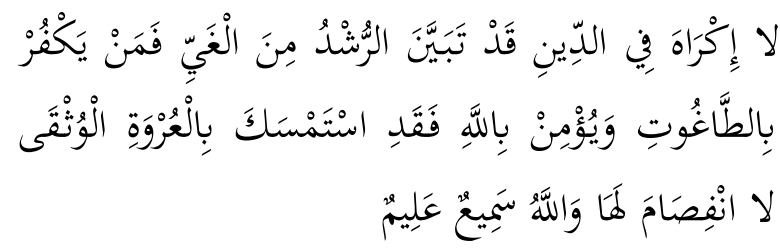

Tidak ada paksaan untuk (memasuki) agama (Islam); Sesungguhnya telah jelas jalan yang benar daripada jalan yang sesat. Karena itu Barangsiapa yang ingkar kepada Thaghut dan beriman kepada Allah, Maka Sesunggubnya ia telah berpegang kepada bubul tali yang Amat kuat yang tidak akan putus. dan Allab Maba mendengar lagi Maha mengetahui.

Pada ayat tampak jelas bahwa tidak ada paksaan untuk memasuki agama Islam. Jadi adanya pernyataan bahwa agama Islam disebarkan dengan pedang merupakan hal

11 Kasjim Salenda, Terorisme dalam Perspektif Hukum Islam, Ullumuna: Jurnal Studi Keislaman, Volume XIII, No. 1. Juni 2009, h. 83 
yang tidak benar. Sebab Alquran sendiri yang menegaskan bahwa tidak ada paksaan dalam memeluk Islam.

Di samping itu, bukankah secara tegas Alquran menuntun agar kaum muslim berdakwah dengan hikmah, memberi peringatan dengan baik, berdialog dan bertukar pikiran dengan cara yang terbaik (Qs. Al-Nahl ayat 125), serta telah ditegaskan-Nya pula agar senantiasa menolak kejahatan. (Qs. Fushilat ayat 34)

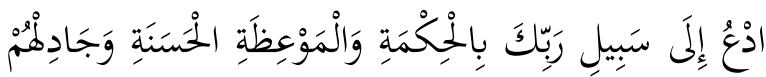

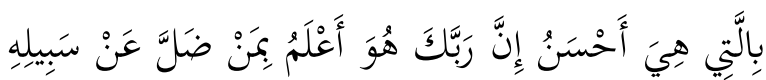

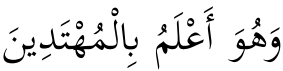

serulah (manusia) kepada jalan Tuban-mu dengan bikmah dan pelajaran yang baik dan bantablah mereka dengan cara yang baik. Sesunggubnya Tubanmu Dialah yang lebih mengetahui tentang siapa yang tersesat dari jalan-Nya dan Dialah yang lebih mengetahui orang-orang yang mendapat petunjuk.

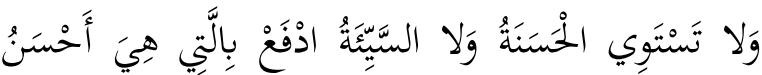

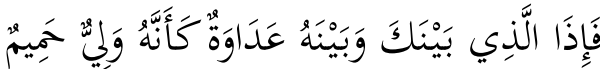

Dan tidaklah sama kebaikan dan kejahatan. Tolaklah (kejahatan itu) dengan cara yang lebih baik, Maka tiba-tiba orang yang antaramu dan antara Dia ada permusuban seolah-olah telah menjadi teman yang sangat setia.

Ada orang yang salah paham, karena kedangkalan pengetahuannya, sehingga mengira bahwa Alquran memerintahkan mempersiapkan kekuatan untuk melakukan teror. Ini, menurut mereka, karena Allah Swt berfirman pada Surat Al-Anfal ayat 60;

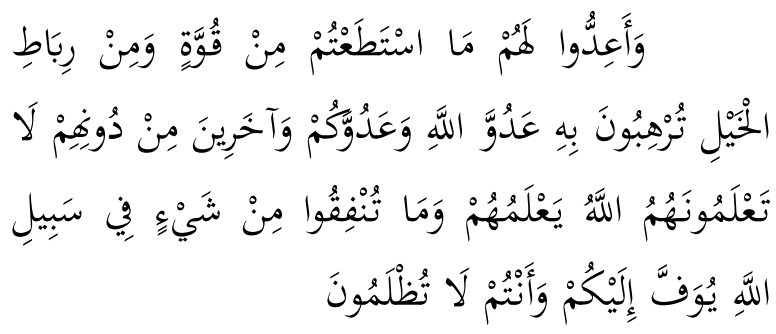

Dan siapkanlah untuk menghadapi mereka kekuatan apa saja yang kamu sanggupi dan dari kuda-kuda yang ditambat untuk berperang yang dengan persiapan itu) kamu menggentarkan musub Allah dan musubmu dan orang orang selain mereka yang kamu tidak mengetabuinya; sedang Allab mengetabuinya. apa saja yang kamu nafkahkan pada jalan Allah niscaya akan dibalasi dengan cukup kepadamu dan kamu tidak akan dianiaya (dirugikan).

Mereka menganggap kata turbibuun yang digunakan ayat di atas berarti meneror, padahal maksud dari kata tersebut adalah menggentarkan. Memang, dalam perkembangannya dewasa ini, kata irhab diartikan dengan teror, tetapi makna tersebut tidak digunakan, bahkan tidak dikenal, oleh Alquran. Demikian pula halnya dengan seluruh kata yang berakar sama yang terdapat dalam kitab suci itu. ${ }^{12}$ Allah Swt memerintahkan mempersiapkan kekuatan, bukan digunakan untuk mengancam dan menakut-nakuti orang, tetapi untuk membuat mereka yang bermaksud jahat berhitung seribu kali sebelum melangkah. Memiliki kekuatan bukan untuk menganiaya, tidak juga untuk memusnahkan, tetapi sekedar untuk menggetarkan. Sebab, penggunaan kekuatan sebaiknya dihindari. Kalaupun digunakan, ia digunakan untuk menghadapi musuh Allah. ${ }^{13}$

Di sisi lain ditemukan tuntunan Alquran dan Sunnah untuk bersikap lemah lembut, dan memberi kemudahan. Nabi Musa dan Nabi Harun diperintahkan menghadapi Firaun dengan ucapan yang lemah lembut, sebagaimana dalam QS. Thaha ayat 44;

$$
\text { فَقُولَا لَهُ قَوْلاً لَيِّا لَعَلَّهُ يَتَذَكَّرُ أَوْ يَخْشَى }
$$

Maka berbicaralah kamu berdua kepadanya dengan kata-kata yang lemah lembut, Mudah-mudahan ia ingat atau takut.

12 M. Qurasih Shihab, Secercab Cahaya Ilabi, ( Bandung; Mizan, 2007), h. 274

${ }^{13}$ Ibid. 
Kedua Nabi itu diperintahkan bersikap demikian agar hati Fir'aun tergugah, dan seperti terbaca, kelemahlembutan pun dapat menimbulkan rasa takut. Perintah ini merupakan salah satu cirri penyampaian agama, dan karena itu pula, Nabi Muhammad Saw juga diperintahkan untuk bersikap lemah lembut sebagaimana dalam Qs. Ali Imran ayat 159;

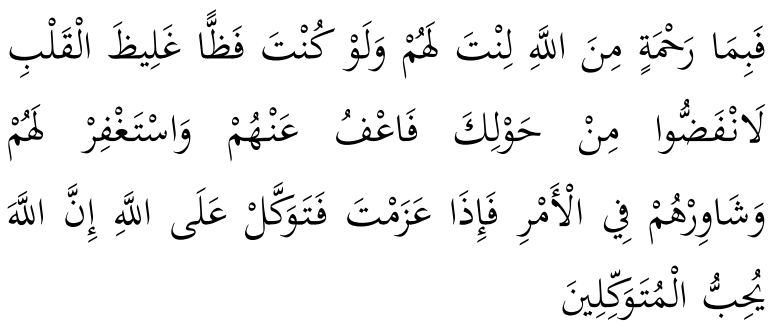

Maka disebabkan rabmat dari Allah-lab kamu Berlaku lemah lembut terhadap mereka. Sekiranya kamu bersikap keras lagi berbati kasar, tentulah mereka menjaubkan diri dari sekelilingmu. karena itu ma'afkanlah mereka, mohonkanlah ampun bagi mereka, dan bermusyawaratlah dengan mereka dalam urusan itu. kemudian apabila kamu telah membulatkan tekad, Maka bertawakkeallah kepada Allah. Sesunggubnya Allah menyukai orang-orang yang bertawakeal kepada-Nya.

Dari sini, dan dalam berbagai kesempatan, Nabi Saw mengingatkan sikap dasar dalam menyampaikan dan memperjuangkan ide dan cita-cita, yaitu permudablah dan jangan persulit. Berilah kabar gembira dan jangan menjaubkan ( HR. Bukhari dan Muslim melalui Anas bin Malik) Ini, karena, seperti sabdanya, " sesunggubnya Allab bersifat lemah lembut, dan menyayangi kelemahlembutan dalam segala persoalan." (HR. Bukhari dan Muslim melalui Aisyah) Dalam riwayat lain dinyatakan, "Allah menganugerabkan dengan kelemablembutan apa yang tidak dianugerabkean-Nya melalui kekerasan dan kesulitan, babkean apa yang tidak dianugerabkan dengan cara yang lain" (HR Muslim).

M. Qurasih Shihab menyatakan bahwa sepanjang penelitiannya, tidak terdapat dalam Alquran anjuran bersikap keras, kecuali dalam dua hal ${ }^{14}$. Pertama, dalam peperangan, misalnya, firman Allah (Qs. Al-Anfal ayat 12);

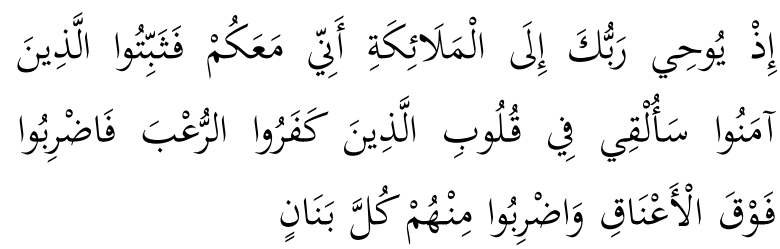

(ingatlab), ketika Tuhanmu mewahyukan kepada Para Malaikat: "Sesunggubnya aku bersama kamu, Maka tegubkan (pendirian) orang-orang yang telab beriman". kelak akan aku jatubkan rasa ketakutan ke dalam hati orang-orang kafir, Maka penggallah kepala mereka dan pancunglah tiap-tiap ujung jari mereka.

Kedua, ketika penjatuhan sanksi hukum oleh yang berwenang. Bacalah firman-Nya dalam konteks penjatuhan sanksi bagi para pezina, Qs. An-Nur ayat 2;

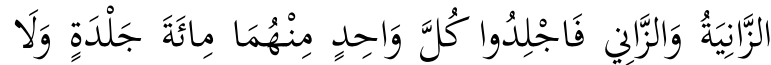

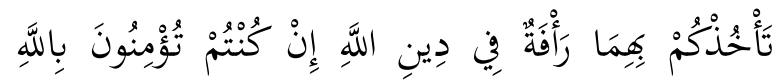

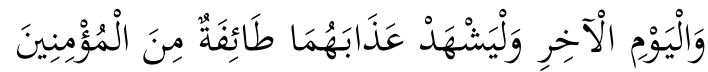

Perempuan yang berzina dan laki-laki yang berzina, Maka deralah tiap-tiap seorang dari keduanya seratus dali dera, dan janganlah belas kasiban kepada keduanya mencegah kamu untuk (menjalankan) agama Allah, jika kamu beriman kepada Allah, dan hari akbirat, dan bendaklah (pelaksanaan) bukuman mereka disaksikan oleh sekumpulan orang-orang yang beriman.

Dalam dua konteks di atas, wajar jika ada adanya anjuran bersikap keras, karena kondisi perang menuntut untuk melakukan perlawanan. Namun hal ini bukanlah berarti disamakan dengan konsep terorisme. Karena sebagaimana yang telah dijelaskan sebelumnya bahwa terorisme itu merupakan tindakan kekerasan sepihak dari seorang atau kelompok yang menimbulkan korban secara massal dan tidak pandang bulu, serta menimbulkan kerusakan atau kehancuran terhadap obyekobyek vital yang strategis atau lingkungan

${ }^{14}$ Ibid., h. 275 
hidup atau fasilitas publik atau fasilitas internasional.

Adapun Allah tidak menyukai orangorang yang berbuat kerusakan sebagaimana firman-Nya dalam surat al-Baqarah ayat 205;

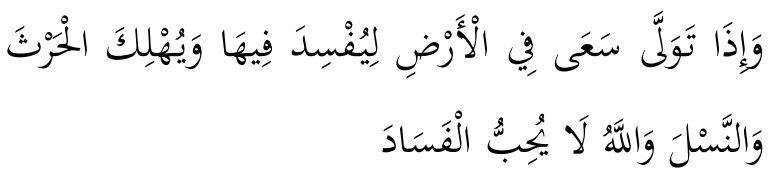

Dan apabila ia berpaling (dari kamu), ia berjalan di bumi untuk. Mengadakan kerusakan padanya, dan merusak tanam-tanaman dan binatang ternak, dan Allah tidak menyukai kebinasaan.

Golongan manusia semacam ini, apabila ia telah berlalu dan meninggalkan orang yang ditipunya itu, ia melaksanakan tujuannya yang sebenarnya. Ia melakukan kerusakan-kerusakan diatas bumi: tanamantanaman dan buah-buahan dirusak dan binatang ternak dibinasakan, apalagi kalau mereka sedang berkuasa, dimana-mana mereka berbuat sesuka hatinya, wanita-wanita dinodai. Tidak ada tempat yang aman dari perbuatan jahatnya. Fitnah dimana-mana mengancam, masyarakat merasa ketakutan, dan rumah tangga serta anak-anak berantakan karena tindakannya yang salah.

Sifat-sifat yang semacam ini, tidak disukai Allah SWT sedikitpun. Dia murka terhadap orang-orang yang berbuat demikian, begitu juga terhadap orang-orang yang perbuatannya kotor, dan menjijikan. Apatah lagi perbuatan teror yang menimbulkan kerusakan yang besar, tentunya hal ini merupakan perbuatan yang sangat dilarang Allah.

Untuk itu sudah jelas bahwa Alquran tidaklah menyeru umat untuk melakukan tindakan kekerasan apalagi tindakan terorisme. Adapun menurut penulis, adanya kessalahpamahan sekelompok umat dalam pemaknaan kata "jihad" sehingga mereka melakukan tindakan terorisme yang menurut mereka adalah salah satu bentuk jihad terhadap orang kafir. Maka sekarang ini kita banyak melihat prilaku teror ditujukan kepada assetasset yang berhubungan dengan Amerika/ Yahudi, seperti hotel JW Marriot dan Ritz Calten beberapa tahun belakangan ini. Dalam benak para aktifis muslim, jihad lebih dipahami dalam kerangka balas dendam karena kafir telah memerangi muslim tanpa batas, maka muslim wajib membalasnya dengan memerangi kafir secara tanpa batas pula. Menurutnya, dalam ketentuan syari'ah, jihad berarti berperang melawan kaum kafir yang memerangi Islam dan kaum muslimin. Konsep inilah yang mereka sebut dengan jibad fi sabilillah.

Dalam pemahamannya, ayat Alquran pertama tentang jihad yang diturunkan kepada Nabi Muhammad adalah memerangi kaum kafir sebatas yang memerangi Islam. Sebagaimana dalam firman Allah dalam Surat Al-Baqarah ayat 190;

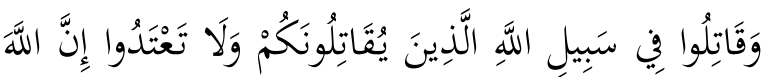

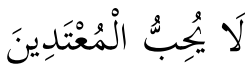

"Dan perangilah di jalan Allah orang-orang yang memerangi kamu. Dan janganlah kamu melampaui batas. Sesunggubnya Allah tidak menyukai orangorang yang melampaui batas".

Setelah kita cermati kembali tentang Islam sekaligus peribadi Rasulullah SAW yang diamanati oleh Allah SWT untuk menyebarkan Islam ke seluruh umat manusia, maka jelas sekali bahwa terorisme sama sekali tidak dikenal, bahkan bertolak belakang dengan ajaran Islam. Terorisme dengan menggunakan kekerasan, kekejaman serta kebengisan dan cara-cara lain untuk menimbulkan rasa takut dan ngeri pada manusia untuk mencapai tujuan. Sedangkan Islam dengan lemahlembut, santun, membawa kabar gembira tidak menjadikan manusia takut dan lari, serta membawa kepada kemudahan, tidak menimbulkan kesusahan, dan tidak ada paksaan. 
Tampak jelas bahwa kedua hal tersebut mempunyai tujuan yang berbeda. Terorisme biasanya digunakan untuk tujuan politik, dan kekuasaan. Sedangkan Islam bertujuan untuk menuntun manusia dalam mencapai kebahagiaan hidupnya dengan dilandasi rasa kasih sayang hanya semata-mata mengharap ridha Allah SWT. Jadi dengan demikian, jelas dan teranglah bahwa terorisme dalam pandangan agama Islam tidak dibenarkan, dan jauh dari tuntunan Islam

\section{HAKIKAT JIHAD}

Diskursus tentang jihad selalu menyita perhatian dari berbagai kalangan, baik dari kalangan Islam sendiri maupun non-muslim. Bagi kalangan Islam ajaran jihad adalah inheren di dalamnya dan setiap muslim secara otomatis adalah seorang mujahid. Sementara bagi kalangan non muslim ajaran jihad merupakan pintu masuk untuk menyerang dan mendiskriditkan Islam. Oleh kalangan Barat istilah tersebut sering dipahami sebagai perang suci untuk melakukan penyerangan dan pemaksaan terhadap orang-orang kafir agar masuk Islam. Jelas hal ini memunculkan citra negative terhadap Islam dan umat Islam. ${ }^{15}$

Kata jahd atau jubd artinya kekuatan, kekuasaan, atau kesanggupan. Kata ini dapat juga berarti masyaqah (kesukaran atau kesulitan). ${ }^{16}$ Kata jahada-yajbadu-jabdan dan kata ijtahada maknanya sama dengan kata jada (bersungguh-sungguh) ${ }^{17}$. Kitab-kitab bahasa Arab menyatakan bahwa kata jihad dan mujahadah berarti "menguras kemampuan dan melawan musuh." 18 Dengan demikian, jihad

\footnotetext{
15 Nasaruddin Umar, Deradikalisasi Pemahaman..., h 100

16 Ibnu Faris, Maqayis al-Lughah, (Kairo: Mkatab al-Khanji, t.th), h. 486. Ahmad Warson Munawwir, Kamus al-Munawwir, ( Surabaya: Pustaka Progresif, 1997), h. 217

17 Abdul Baqi Ramdun, Jihad Jalan Kami, penerjemah: Imam Fajaruddin, ( Solo: Era Intermedia, 2002), h. 12

18 Ali Abdul Halim Mahmud, Rukun Jihad: Kajian Tuntas tentang Konsep Mempertahankan Eksistensi
}

berarti berjuang keras dan berusaha maksimal untuk melawan sesuatu yang keliru.

Menurut pengertian terminologis (istilah), jihad adalah mengerahkan segala kemampuan untuk menangkis serangan dan menghadapi musuh yang tidak tampak, yaitu hawa nafsu syaithan dan musuh yang tampak yaitu orang kafir. ${ }^{19}$ Menurut Abdul Karim Zaidan sebagaimana yang dikutip Nasaruddin Umar, para ulama mendefinisikan jihad ke dalam dua pengertian, pertama, segala usaha dan upaya sekuat tenaga serta kesediaan menanggung kesulitan di dalam memerangi dan menahan agresi musuh dalam segala bentuknya. Jihad seperti ini disebut dengan alQital atau al-harb. Kedua, jihad dapat juga bermakna mencurahkan segala upaya dengan sungguh-sungguh dan berkelanjutan untuk menjaga dan meninggikan agama Allah Swt. ${ }^{20}$ Jihad berarati segala bentuk usaha maksimal untuk penerapan ajaran Islam dan pemberantasan kejahatan serta kezaliman, baik terhadap diri sendiri maupun dalam masyarakat.

Dalam Alquran maupun Hadis, katakata jihad mengandung pengertian umum. Tidak dipungkiri bahwa adakalanya jihad digunakan pada konteks pertempuran, peperangan, ekspedisi militer. Dalam firman Allah Surat al-Taubah ayat 41.

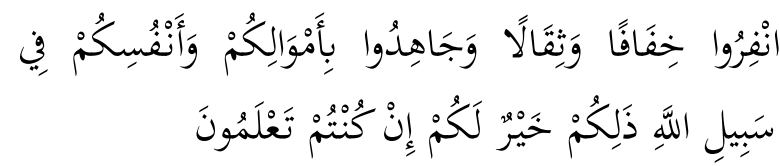

Berangkatlah kamu baik dalam Keadaan merasa ringan maupun berat, dan berjibadlah kamu dengan

Umat, penerjemah: Khozin Abu Faqih dan Fachruddin, (Jakarta: al-ittishom cahaya umat, 2001), h. 31

${ }_{19}$ Raghib al-asfahani mengatakan bahwa jihad dalam al-qur'an mencakup tiga hal, yaitu berjuang dengan sungguh-sungguh melawan musuh untuk menegakkan agama Allah, berjuang sungguh-sungguh melawan syaithan yang selalu menyebabkan munculnya kejahatan dan berjuang sungguh-sungguh melawan nafsu yang selalu mengajak pada kemungkaran dan kemaksiatan. Al-Raghib al-Asfahani, Mu'jam Mufradat alFadz al-Qur'an, ( Beirut: Dar al-Fikr, t.th), h. 208 
harta dan dirimu di jalan Allah. yang demikian itu adalah lebih baik bagimu, jika kamu mengetahui.

Namun jihad dalam konteks ini mempunyai persyaratan tertentu, di antaranya bahwa perang tersebut harus bersifat defensive. hal ini sesuai dengan firman Allah swt dalam Alquran".

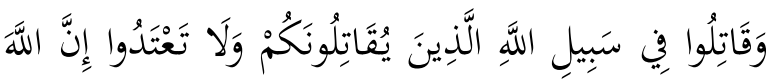
لَا يُحِبُُْ الْهُعْتَدِينَ

Dan perangilah di jalan Allah orang-orang yang memerangi kamu, (tetapi) janganlah kamu melampaui batas, karena Sesunggubnya Allah tidak menyukai orang-orang yang melampani batas. (QS. Al-Baqarah : 190)

Perang dilakukan untuk menghilangkan fitnah dan mewujudkan kebajikan dam keadilam, sebagaimana firman Allah;

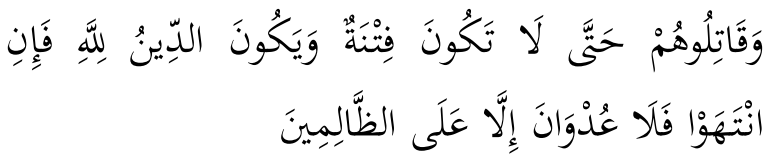

Dan perangilab mereka itu, sebingga tidak ada fitnah lagi dan (sehingga) ketaatan itu hanya semata-mata untuk. Allah. jika mereka berhenti (dari memusubi kamu), Maka tidak ada permusuban (lagi), kecuali terbadap orang-orang yang zalim. (Qs. Al-Baqarah: 193)
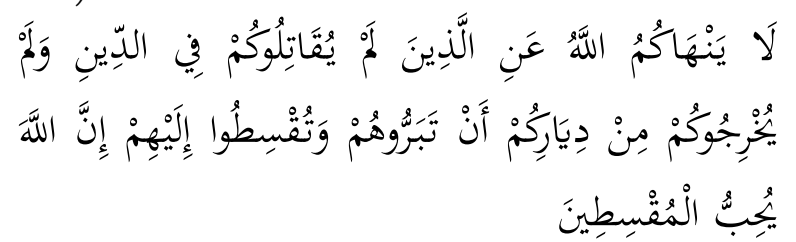

Allah tidak melarang kamu untuk berbuat baik dan Berlaku adil terbadap orang-orang yang tiada memerangimu karena agama dan tidak (pula) mengusir kamu dari negerimu. Sesunggubnya Allah menyukai orang-orang yang Berlaku adil. (Qs. AlMumtahanah: 8)

Makna Jihad tidak hanya pada konteks yang disebutkan di atas, namun kebanyakan makna jihad mencakup segala bentuk kegiatan dan usaha yang maksimal dalam rangka dakwah Islam, amar ma'ruf nabi mungkar.
Ibn al-qayyim al-Jauziyah memberikan istilah jihad am, yakni jihad yang mencakup segala aspek kehidupan baik moral maupun yang bersifat material, terhadap diri sendiri maupun terhadap orang lain ditengah-tengah masyarakat. Jihad seperti ini dapat dilakukan dengan pengorbanan jiwa, tenaga, waktu, ilmu pengetahuan yang dimiliki. Jihad ini juga berkesinambungan tanpa harus dibatasi oleh ruang dan waktu, bisa dilakukan terhadap musuh nyata (seperti kemiskinan, kebodohan, keterbelakangan), setan, atau hawa nafsu. Sebagaimana firman Allah;

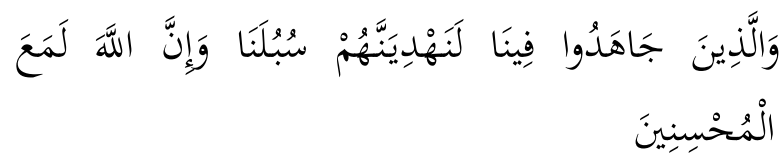

Dan orang-orang yang berjibad untuk (mencari keridhaan) Kami, benar- benar akan Kami tunjukkan kepada mereka jalan-jalan kami. dan Sesunggubnya Allab benar-benar beserta orang-orang yang berbuat baik.(Qs. Al-Ankabut: 69)

Dari pengertian ini, berarti jihad harus berlangsung secara berkesinambungan, baik dalam situasi aman maupun perang, karena tegaknya Islam sangat ditentukan oleh semangat jihad dalam semua aspek kehidupan. Sebaliknya, jika semangat jihad telah memudar maka etos kerja akan menurun, sikap apatis akan muncul yang akhirnya akan membawa pada kehancuran umat Islam itu sendiri.

Ahli Tafsir Alquran, Imam al-Thabari, mengemukakan bahwa terdapat ayat-ayat Alquran yang memberikan justifikasi untuk melakukan jihad dengan tujuan membuat dunia tahu tentang jalan ilahi, sehingga manusia dapat mengikuti kemauan Tuhan sebagaimana disampaikan melalui Islam. Di sini jihad dipandang hampir sama atau berkaitan dengan dakwah Islam.

Karena itu, jumbur ulama berpendapat, kewajiban jihad dapat ditunaikan dalam empat bentuk; dengan hati, lidah, tangan dan pedang. Jihad bentuk pertama berkenaan dengan perlawanan terhadap iblis dan rayuannya 
kepada manusia untuk melakukan kejahatan; jihad internal, jihad melawan hawa nafsu dipandang sangat penting, sehingga disebut aljihad al-akbar. Jihad jenis kedua dan ketiga dijalankan terutama untuk menegakkan kebenaran dan mencegah kemungkaran. Jihad jenis keempat sama artinya dengan perang dan berkenaan dengan pertempuran melawan orang-orang kafir dan musuh-musuh Islam.

Makna jihad yang multi tafsir, membuat banyak intelektual yang mencoba memberikan penafsiran dan landasan hukum mengenai pentingnya jihad, namun adakalanya kesalahan dalam menginterpretasi ayat Alquran maupun Hadis mengenai jihad membuat kesalahpahaman dalam memaknai kata jihad itu sendiri. Di antara orientalis yang melakukan studi tentang jihad berkesimpulan bahwa jihad adalah perang suci untuk melawan orang kafir, sehingga muncul pernyataan bahwa Islam disebarkan dengan pedang. Kesalahan interpretasi juga terjadi dikalangan umat Islam sendiri, seperti adanya oknum yang melakukan tindakan bom bunuh diri dan melakukan teror mengatasnamakan jihad.

Padahal dalam Alquran ditegaskan bahwa jihad itu digunakan tidak hanya konteks peperangan (untuk mempertahankan harga diri Islam), namun semangat jihad harus melekat dalam semua aspek kehidupan. Secara tegas dapat dikatakan bahwa ajaran jihad bukanlah terorisme dan Islam bukanlah agama teroris.

\section{KESIMPULAN}

Terorisme kerap kali disalahpahami sebagai ajaran jihad. Padahal dua hal tersebut sangatlah jauh berbeda. Jihad adalah berjuang dengan sungguh-sungguh menurut syariat Islam. Jihad dilaksanakan untuk menjalankan misi utama manusia yaitu menegakkan agama Allah atau menjaga agama tetap tegak, dengan cara-cara yang sesuai dengan garis perjuangan para Rasul dan Alquran.

Sedangkan Terorisme adalah seranganserangan terkoordinasi yang bertujuan membangkitkan perasaan teror terhadap sekelompok masyarakat. Terorisme tidak bisa dikategorikan sebagai Jihad, Jihad dalam bentuk perang harus jelas pihak-pihak mana saja yang terlibat dalam peperangan, Alasan perang tersebut terutama dipicu oleh kezaliman kaum Quraisy yang melanggar hak hidup kaum Muslimin

Alquran berisi tuntunan untuk selalu mengajak orang kepada perdamaian dan kerukunan, dan tidak pernah mengizinkan seseorang untuk memerangi siapa pun yang tidak bersalah. Namun dalam kondisi dimana umat Islam diperangi, maka Islam pun mengenal peperangan melawan kebatilan dengan melakukan kontak senjata, dengan syarat harus ada dakwah kepada mereka terlebih dahulu, baik dengan lisan mapun tulisan. Bahkan cara berdakwah pun diajarkan dengan cara yang baik dan bijaksana. 


\section{DAFTAR KEPUSTAKAAN}

Ali Abdul Halim Mahmud, Rukun Jibad: Kajian Tuntas tentang Konsep Mempertahankan Eksistensi Umat, penerjemah: Khozin Abu Faqih dan Fachruddin, Jakarta: al-ittishom cahaya umat, 2001.

Al-Raghib al-Asfahani, Mu'jam Mufradat al-Fadz, Alquran, Beirut: Dar al-Fikr, t.th

Departemen Pendidikan dan Kebudayaan, Kamus Besar Bahasa Indonesia, Jakarta: Balai Pustaka, 1990

Faris, Ibnu, Maqayis al-Lughah, Kairo: Mkatab al-Khanji, t.th

Hakim, Lukmanul, Terorisme di Indonesia, Surakarta: FSIS, 2004

Hammad, Suhailah Zain al-Abiddin, Bagaimana Mengatasi Terorisme, Jakarta: Zikrul Hakim, 2005

Muladi, "Demokrasi, HAM dan Reformasi Hukum di Indonesia", Jakarta: The Habibie Center, 2002

Munawwir, Ahmad Warson, Kamus al-Munawwir, Surabaya: Pustaka Progresif, 1997

Mustofa, Muhammad , "Memahami Terorisme: SuatuPerspektif Kriminolog, Jurnal KriminologiIndonesia FISIP UI, Jakarta: 2002

Paulus, Loudewijk. F. , Terorisme”, http://buletinlitbang.dephan.go.id

Ramdun, Abdul Baqi, Jihad Jalan Kami, penerjemah: Imam Fajaruddin, Solo: Era Intermedia, 2002

Shihab, M. Qurasih , Secercah Cahaya Ilabi, Bandung; Mizan, 2007

Umar, Nasaruddin, Deradikalisasi Pemabaman Alquran dan Hadis, Jakarta: Rahmat Semesta Center, 2008 